Instructions/Template for Preparing Manuscript for Jendela Nursing Journal

\title{
The Anxiety Level of Mother Presectio Caesar with Benson's Relaxation Therapy
}

\author{
Jek Amidos Pardede ${ }^{1}$, Irvandy Tarigan ${ }^{1}$ \\ ${ }^{1, N u r s i n g ~ S t u d y ~ P r o g r a m, ~ P h a r m a c y ~ a n d ~ H e a l t h ~ S c i e n c e s, ~ S a r i ~ M u t i a r a ~ S T I K E S ~}$ \\ Corresponding author: jekpardedemi@rocketmail.com
}

\begin{abstract}
Background: Sectio caesar is a surgical action to remove a baby from the uterus by an incision in the mother's abdominal wall that aims to save the mother and baby so that the mother can deliver the baby in a healthy condition and can be born safely. Sectio Caesar often makes the mother experience anxiety that affects physical conditions that can interfere with the process of the cesarean section, so it requires the treatment of Benson in dealing with anxiety.

Purpose: Analyse differences between before and after Benson's relaxation therapy on pre-sectional Cesarean anxiety level.

Methods: The study used the Quasy experiment One Group pre and Post-test design to. The technique of taking samples using purposive sampling and the number of samples wee 14 respondents. Data collection used a questionnaire. Data analising used McNemar test with a significance of $95 \%$ and $p<0.05$.

Results: The anxiety level of pre-cesarean section mothers before was $78.6 \%$ and after Benson therapy was $85.7 \%$ with a $p$-value $0.004(<0.05)$.

Conclusion: The Benson's relaxation therapy is working on pre-section cesarean mothers by decreassing mothers' anxiety levels.
\end{abstract}

Keywords:

Benson's Relaxation Therapy; Sectio Caesar; Anxiety.

\section{LATAR BELAKANG}

Persalinan normal merupakan proses mengeluarkan bayi dari rahim ibu dengan bayi cukup bulan tanpa ada masalah kehamilan namun apabila terdapat masalah kehamilan baik pada ibu ataupun pada janin, proses persalinan yang dilakukan dalam hal ini dapat berupa tindakan sectio caesar (Yanti, 2015). Sectio caesar merupakan suatu tindakan pembedahan untuk mengeluarkan bayi dari rahim dilakukan dengan cara insisi pada dinding perut ibu yang bertujuan untuk menyelamatkan ibu dan bayi sehingga ibu dapat melahirkan bayi dalam keadaan yang sehat dan dapat lahir dengan selamat (Sumelung, et al, 2014). Menurut Solehati \& Rustina (2015) Ada beberapa alasan untuk melakukan operasi caesar dari beberapa temuan penelitian bahwa alasan untuk melakukan operasi caesar adalah berat bayi lebih dari normal, jarak janin, distosia, plasenta previa, solusio 
plasenta, penurunan persentase janin dan malposisi. Selain itu, ada keinginan untuk melakukan operasi caesar dengan pencarian ibu tanpa adanya indikasi kebidanan.

Tindakan sectio caesar dapat dibedakan menjadi dua yaitu, sectio caesar terencana yang merupakan tindakan operasi yang sudah direncanakan karena ada masalah kesehatan pada ibu sehingga tidak memungkinkan untuk melahirkan secara normal dan sectio caesar darurat dilakukan ketika proses persalinan normal sedang berlangsung, namun karena suatu keadaan kegawatan maka sectio caesar harus segera dilakukan (Oxorn \& Forte, 2010).

Menurut WHO (2013), indikator persalinan dengan metode sectio caesarterencana ataupun darurat terus meningkat diseluruh dunia, khususnya negara-negara berpenghasilan menengah ke atas dan negara tersebut diantaranya Australia (32\%), Brazil (54\%) dan Colombia (43\%), sedangkan di Indonesia, Data Riskesdas (2013) menunjukkan kelahiran dengan sectio caesar sebesar 9,8\% dengan proporsi tertinggi DKI Jakarta (19,9\%), Sumatera Barat (14\%) dan terendah di Sulawesi Tenggara (3,3\%) dan di RSUD Dr. Pirngadi Medan terdapat 31,37\% pertahunnya, dan RSUD Sidikalang tahun 2017 terdapat 57,6\%.

Sectio saecar adalah tindakan yang harus cepat dilaksanakan untuk menyelamatkan ibu dan janin karena adanya gangguan kehamilan sehingga membuat ibu merasa cemas. Tindakan sectio caesar mempengaruhi psikologi ibu yaitu perasaan cemas karena sectio caesar memiliki komplikasi seperti infeksi luka, perdarahan, resiko kematian yang serius, operasi gagal dan nyeri pasca pembedahan. Cemas merupakan munculnya perasaan tidak aman, tegang dan kawatiran kibat suatu kondisi yang membahayakan namun penyebabnya belum diketahui dengan jelas (Perdana, 2018). Perasaan cemas pada ibu pre sectio Caesar dapat menimbulkan kondisi yang tidak stabil yang ditandai dengan terjadinya peningkatan tekanan darah, frekuensi nadi, frekuensi napas, mual/muntah dan gelisah yang akan menganggu proses operasi itu sendiri sehingga diperlukan cara yang tepat dalam mengatasi kecemasan pada ibu (Benson \& Ralp C, 2009). Kecemasan pada ibu presectio caesar didasari oleh tindakan sectio caesar yang memiliki komplikasi seperti infeksi luka, perdarahan, resiko kematian yang serius, operasi gagal dan nyeri pasca pembedahan (Perdana, 2018).

Ditemukan beberapa pengobatan dalam mengatasi kecemasan baik tindakan farmakologi maupun non farmakologi. Tindakan non farmakologi dapat berupa teknik distraksi dan relaksasi. Teknik relaksasi dapat menurunkan kecemasan pada ibu hamil yang akan menjalani sectio caesar salah satunya adalah Benso's Relaxation Therapy. Benson's Relaxation Therapy merupakan kombinasi antara teknik respon relaksasi pernafasan dan sistem keyakinan individu. Menurut Solehati \& Rustina (2015) Relaksasi ini adalah kombinasi dari teknik respons relaksasi dengan sistem kepercayaan individu/faktor keyakinan (berfokus pada bentuk ekspresi tertentu dari nama-nama Tuhan atau kata yang memiliki perasaan menenangkan bagi klien) berulang kali diucapkan dengan irama teratur dengan berserah diri pada Tuhan.

Manfaat dari relaksasi benson terbukti memodulasi stress terkait dengan kondisi seseorang seperti Stres, cemas, mengontrol gula darah , nyeri, depresi, hipertensi, meningkatkan kualitas hidup, dan lai-lain. Yusliana, et al (2016). Mengatakan menurut 
peneliti berdasarkan berbagai teori dan penelitian pendukung, maka Benson's Relaxation Therapy dapat digunakan untuk melawan cemas yang dimanifestasikan dengan stress maupun depresi. Kenanangan yang muncul ini disebabkan karena gelombang alpha otak yang menyebabkan manusia merasakan perasaan gembira dan nyaman. Kelenjar pituitary manusia juga menghasilkan hormon-hormon yang menenangkan yaitu endorphindan encephalin yang bersifat memberikan efek tenang dan nyaman. Sedangkan dari teori homeostasis dalam tubuh manusia akan meningkatkan aktifitas saraf parasimpatik sehingga terjadi penurunan sinstesis hormon katekolamin yang berakibat menurunnya kontraksi otot, penurunan denyut jantung, vasodilatasi pembuluh darah dan penurunan tekanan darah.

Beberapa penelitian dengan menggunakan Benson's Relaxation Therapy seperti: Ma'rifah,(2016) Menurunkan tingkat kecemasan 14,6\% pada pasien kanker serviks di RSUD Margono Soekardjo Purwokerto; Solehati \& Rustina (2015) menurunkan intensitas nyeri wanita setelah Sectio Saecar di RS Cibabat Cimahi; Rambod, et al (2014) menurunkan intesitas nyeri dan meningkatkan kualitas hidup pasien hemodialisis; Paramban, et al (2016) Mengurangi stress pada ibu primigravida; Otaghi, et al (2016) Menurunkan gejala depresi, kecemasan dan stres pada pasien yang menjalani hemodialysis; Kurniasari, et al (2016) Menurunkan kecemasan pasien yang di hemodialisis di RS PKU Muhammadiyah Yogyakart; Kiani, et al (2017) Menurunkan kecemasan pasien hemodialysis di RS Khatam Al Anbia; Gorji, et al (2014) Mengatasi stres, kecemasan, dan persepsi nyeri pasien hemodialisis; Warsono, et al (2019) Menurunkan intensitas nyeri pasien Post Sectio Saecarea di RS PKU Muhammadiyah Cepu; Ratnawati, et al (2018) Mengontrol gula darah pasien diabetes mellitus pada Lansia; Wahyu (2018) Menurunkan nyeri pasca section saecarea; Darmawan (2015) Menurunkan tekanaan darah pada pasien hipertensi.

Berdasarkan survei pendahuluan yang dilakukan di RSUD, tindakan sectio caesar pada tahun 2019 sebanyak 173 orang, jumlah bayi BBLR dengan komplikasi sebanyak 74 orang dan ibu yang cemas menghadapi presectio caesar tidak pernah diberikan tindakan keperawatan untuk menurunkan kecemasannya . Peneliti juga melakukan wawancara kepada beberapa pasien yang akan dilakukan sectio Caesar dan belum pernah diberikan terapi benson di RSUD dengan 2 orang diantaranya mengatakan bahwa mereka merasa tidak tenang dan cemas saat akan dilakukannya tindakan sectio caesar karena baru pertama kali dioperasi dan hal yang dilakukan hanya berdoa, 2 orang lain mengatakan cemas hingga sulit tidur karena mengingat kejadian pada orang lain tentang kematian ibu atau anak setelah dilakukannya tindakan sectio caesar dan tindakan yang dilakukan dalam mengatasi kecemasannya yaitu berdoa dan pasrah, dan yang lainnya mengatakan cemas dengan bayi yang akan dilahirkan cacat karena kurang menjaga kesehatan saat hamil dan tindakan yang dilakukan dalam mengatasi cemasnya yaitu dengan berdoa dan tarik nafas. Penelitian memberikan Benson's Relaxation Therapy untuk menurunkan kecemasan pada ibu pre sectio caesar.

\section{TUJUAN}

Untuk menguji pengaruh Benson's Relaxation Therapy terhadap tingkat kecemasan pada ibu pre sectio caesar. 


\section{METODE}

Penelitian ini menggunakan Quasy experiment One Group pre and Post test design yang bertujuan untuk mengetahui pengaruh sebelum dan sesudah dilakukan Benson's Relaxation Therapy terhadap tingkat kecemasan ibu pre sectio caesar di RSUD Sidikalang. Rancangan ini tidak memiliki kelompok pembanding (kontrol) akan tetapi dilakukan observasi pertama (pre test) yang memungkinkan peneliti menguji perubahan yang terjadi setelah adanya eksperimen. Populasi dalam penelitian ini seluruh ibu presectio caesar di RSUD Sidikalang tahun 2019 berjumlah 273 orang pertahun dan jumlah rata-rata perbulannya berjumlah 23 orang dan 14 orang yang menjadi responden dengan menggunakan tehnik Purposive sampling. Kriteria inklusi penelitian ini adalah mengalami kecemasan, pernah 1-3 kali section saecaer, aborsi tidak lebih dari 2 kali. Kriteria esklusinya adalah ibu yang section saecar yang mendadak dengan kondisi gawat.

Alat pengumpulan data menggunakan kuesioner kecemasan digunakan oleh Pardede, et al (2018) sebanyak 15 pernyataan yang mengandung pernyataan positif dan negatif dengan menggunakan 4 (empat) jawaban yaitu Selalu, Sering, Kadang-kadang dan Tidak pernah. Untuk pernyataan positif jawaban Tidak Pernah diberi skor 1, KadangKadang diberi skor 2, Sering diberi skor 3 dan untuk jawaban Selalu diberi skor 4. Dan untuk pernyataan negatif jawaban Tidak Pernah diberi skor 4, Kadang-Kadang diberi skor 3, Sering diberi skor 2 dan untuk jawaban Selalu diberi skor 1. Kuesioner ini nilai skor tertinggi 60 poin dan skor terendah 15 poin. Berdasarkan hasil dari kuesioner didapatkan penggolongan kecemasan yaitu kecemasan ringan skor 15-30, kecemasan sedang skor 31-45 dan kecemasan berat skor 46-60 dengan nilai cronbach's alfa 0,890.

Benson's Relaxation Therapy dilakukan oleh 1 perawat spesialis keperawatan jiwa, 1 orang perawat professional dan dibantu 5 pegawai rumah sakit. Pemberian Benson's Relaxation Therapy dilakukan hanya 2 kali, 1 kali pada saat ibu presection saecar di ruang rawat dan 1 kali pada saat di ruang tunggu operasi, terapi diberikan selama 15 dengan menggukan SOP (standar operasional prosedur). Uji statistik yang digunakan adalah uji McNemar (menguji perbedaan antara pre dan post data kategorik) dengan derajat kepercayaan $95 \%$ dengan nilai $p<0,05$.

\section{HASIL}

Hasil penelitian tentang data demografi ibu dengan Sectio Caesar $(n=14)$ menunjukkan bahwa rata-rata usia responden adalah 24 tahun dengan pendidikan terakhir mayoritas SMA sebanyak 78,6\%, dan mayoritas ibu pengalaman sectio Caesar adalah 0-1 kali sebanyak $85,7 \%$.

Tabel 1 Tingkat kecemasan sebelum diberikan terapi benson pada ibu Sectio Caesar

$$
(n=14)
$$

\begin{tabular}{ccc}
\hline Kecemasan & $n$ & Prosentase $(\%)$ \\
\hline Ringan & 3 & 21,4 \\
Sedang & 11 & 78,6 \\
\hline
\end{tabular}


Berdasarkan tabel 1, dapat dilihat bahwa kecemasan responden mayoritas sedang sebanyak $78,6 \%$.

Tabel 2 Tingkat kecemasan sesudah diberikan terapi benson pada ibu Sectio Caesar

$$
(n=14)
$$

\begin{tabular}{ccc}
\hline Kecemasan & $n$ & $\%$ \\
\hline Ringan & 12 & 85,7 \\
Sedang & 2 & 14,3 \\
\hline
\end{tabular}

Berdasarkan tabel 2, dapat dilihat bahwa kecemasan responden mayoritas ringan sebanyak $85,7 \%$.

Tabel 3 Tingkat kecemasan sebelum dan sesudah diberikan terapi benson pada ibu pre sectio Caesar

\begin{tabular}{cccccccc}
\hline $\begin{array}{l}\text { Tingkat Kecemasan } \\
\text { Sebelum Diberikan } \\
\text { Terapi Benson }\end{array}$ & \multicolumn{7}{c}{ Tingkat Kecemasan Sesudah Diberikan Terapi Benson } \\
\hline & $n$ & $\%$ & $n$ & $\%$ & $n$ & $\%$ & \\
\hline & 3 & 21,4 & 0 & 0 & 3 & 21,4 & \multirow{2}{*}{0,004} \\
\hline Ringan & 9 & 64,3 & 2 & 14,3 & 11 & 78,6 & \\
Sedang & 12 & 85,7 & 2 & 14,3 & 14 & 100 & \\
\hline Total & & & & & & \\
\hline
\end{tabular}

Berdasarkan tabel 3, dapat diliihat hasil uji statistik dengan uji McNemar menunjukkan bahwa ada perbedaan yang signifikan antara pemberian terapi benson terhadap tingkat kecemasan ibu pre sectio caesar di RSUD Sidikalang dengan nilai $\mathrm{p}$ value $=0,004$ $(p<0,05)$.

\section{PEMBAHASAN}

\section{Tingkat Kecemasan Ibu Pre Sectio Caesar Sebelum Diberikan Terapi Benson}

Hasil penelitian menunjukkan bahwa mayoritas ibu pre sectio caesa rmemiliki tingkat kecemasan sedang sebanyak 78,6\%. Hal ini diperoleh dari hasil jawaban ibu sebanyak 14 orang dan kuesioner tentang kecemasan pre sectio caesar dengan 15 pernyataan banyak yang menjawab sering sehingga menunjukkan bahwa ibu yang akan menjalani sectiocaesar memiliki tingkat kecemasan sedang. Sejalan dengan hasil penelitian Marbun, Pardede, \& Perkasa (2019) bahwa pasien prepartum mayoritas tingkat kecemasan responden rata- rata 21- 34 atau berada diantara kecemasan sedang sampai kecemasan berat hal ini dapat dilihat dari hasil kuesioner ditemukan bahwa mayoritas ibu pre partum mengalami kecemasan, sulit konsentrasi dan gangguan pola tidur.

Menurut Agustini (2012), kecemasan ibu presectio caesar juga dapat dipengaruhi oleh faktor usia, pengetahuan, paritas, pemeriksaan kehamilan, lingkungan dan situasi. Berdasarkan hasil penelitian ini didapat mayoritas usia ibu presectio caesar rata - rata 24,50. Pada usia ini ibu akan memiliki kecemasan menjelang sectio caesar, karena 
merupakan kategori kehamilan pertama sehingga mengalami paritas. Sedangkan ibu yang sudah pernah melakukan tindakan sectio caesar yang memiliki pengalaman yang bisa menurunkan tingkat kecemasan atau sebaliknya, ketika pengalaman yang dialami tidak baik maka akan meningkatkan kecemasan ibu. Pada penelitian ini, ibu yang melakukan sectio caesar mayoritas $0-1$ kali sebanyak $85,7 \%$. Hal ini mebuktikan bahwa kecemasan ibu yang baru pertama kali sectio saecar lebih cemas disbandingkan yang sudah lebih dari satu kali section saecar.

Faktor pengetahuan juga sering dihubungkan dengan pendidikan seseorang, pada penelitian ini didapat mayoritas ibu pre sectio caesar memiliki pendidikan SMA sebanyak 78,6\%. Semakin tinggi jenjang pendidikan ibu presectio caesar maka diharapkan semakin berdampak pada pemahaman tentang tindakan sectio caesar yang dapat mengurangi kecemasan (Hastuti, 2015).

Menurut asumsi peneliti berdasarkan hasil penelitian yang dilakukan bahwa tingkat kecemasan ibu pre sectio caesar sebelum diberikan Benson's relaxation therapy di RSUD Sidikalang mayoritas berada pada tingkat kecemasan sedang. Hal ini perlu Benson's relaxation therapy untuk meningkatkan kepercayaan dalam menurunkan kecemasan untuk meningkatkan keberhasilan section.

\section{Tingkat Kecemasan Ibu Pre Sectio Caesar Sesudah Diberikan Terapi Benson}

Berdasarkan hasil penelitian, setelah diberikan Benson's relaxation therapy pada ibu presectio Caesar menunjukkan bahwa kecemasan Ibu pre sectio caesar mayoritas memiliki tingkat kecemasan ringan sebanyak $85,7 \%$ yang artinya ada penurunan tingkat kecemasan pada ibu. Hal ini diperoleh dari hasil jawaban ibu sebanyak 14 orang dan kuesioner tentang kecemasan presectio caesar dengan 15 pernyataan banyak yang menjawab kadang - kadang sehingga menunjukkan bahwa ibu yang akan menjalani sectiocaesar sesudah Benson's relaxation therapy memiliki tingkat kecemasan ringan.

Kecemasan pada ibu presectio caesar dapat menimbulkan kondisi yang tidak stabil yang ditandai dengan perubahan tanda - tanda vital seperti terjadinya peningkatan tekanan darah, frekuensi nadi, frekuensi napas dan bisa juga menimbulkan gejala mual/muntah dan gelisah yang dapat menganggu proses operasi itu sendiri sehingga diperlukan cara yang tepat dalam mengatasi kecemasan pada ibu salah satunya terapi benson (Benson \& Ralp C, 2009).

Benson's relaxation therapy merupakan kombinasi dari teknik respon relaksasi pernafasan dan sistem keyakinan ibu. Teknik respon relaksasi pernafasan dapat menurunkan asupan oksigen dan menurunkan ketegangan otot dan tulang sedangkan sistem keyakinan individu dapat menimbulkan perasaan tenang sehingga menurunkan kecemasan. Menurut Hendryanto (2012) Secara fisiologis saat seseorang masuk relaksasi, gelombang pikirannya masuk ke gelombang alfa frekuensinya 7-14 hertz atau lebih dalam lagi ke gelombang theta frekuensinya 4-7 hertz. Ketika pikiran masuk ke gelombang ini, manusia menghasilkan zat endorphin alami yang menghasilkan sensasi nyaman dan tenang. Sehinggan relaksasi ini mampu menurunkan kecemasan.

Hal ini sejalan dengan penelitian yang dilakukan oleh Purwokerto (2016) menunjukkan ada Pengaruh Relaksasi Benson Terhadap Tingkat Kecemasan Pasien Kanker Serviks 
Di RSUD Margono Soekardjo Purwokerto dengan penurunan tingkat kecemasan sebanyak $14,6 \%$. Begitu juga dengan penelitian yang dilakukan oleh Poorolajal et al (2016) tentang keefektifan teknik relaksasi benson terhadap kecemasan pasien pre operasi di RS. Ekbatan dan Esbat Iran dengan nilai $p$ value $0.001(<\alpha=0,05)$.

Dalam penelitian ini, ada juga ibu presectio caesar yang tingkat kecemasannya tidak mengalami penurunan. Hal ini dibuktikan dari hasil analisa kuesioner bahwa ibu presectio caesar masih merasa bahwa sesuatu yang buruk akan terjadi pada saat operasi berlangsung dan tegang bila membayangkan dokter akan membelah bagian tubuh yang akan dioperasi sebanyak 14, $3 \%$.

Faktor keberhasilan terapi benson dapat dipengaruhi oleh beberapa faktor diantaranya perbedaan tingkat kepercayaan atau keyakinan ibu terhadap pengucapan peneliti yang harusnya dapat menimbulkan rasa percaya diri sebelum sectio caesar. Lingkungan juga yang tidak tenang dapat mengganggu keefektifan pengulangan kata atau frase sehingga akan sulit menghilangkan pikiran yang mengganggu atau semakin cemas dan sikap pasif ibu juga sangat penting karena berguna untuk mengabaikan pikiran - pikiran yang mengganggu sehingga fokus pada pengulangan kata atau frase namun apabila ibu tidak bersikap pasif maka akan mengganggu konsentrasi pada pengulangan kata sehingga tidak dapat menenangkan pikirannya (Ma'rifah, 2016).

Menurut asumsi peneliti berdasarkan hasil penelitian yang dilakukan bahwa tingkat kecemasan ibu pre sectio caesar sesudah diberikan terapi benson di RSUD Sidikalang mayoritas berada pada tingkat kecemasan ringan, artinya terapi benson dalam meningkatkan kepercayaan pada ibu pre sectio caesar berhasil untuk menurunkan tingkat kecemasannya dalam menghadapi tindakan sectio caesar yang akan dilakukan.

\section{Perbedaan Tingkat Kecemasan Ibu Post Sectio Caesar Sebelum Dan Setelah Diberikan Terapi Benson}

Berdasarkan Hasil Uji Statistik Menggunakan Uji McNemardidapat ada pengaruh tingkat kecemasan pada ibu pre sectio caesar sebelum dan setelah diberikan terapi benson di RSUD Sidikang dengan nilai $\mathrm{p}$ value $=0,004$ yang artinya ada pengaruhsebelum dan sesudah dilakukan terapi benson terhadap tingkat kecemasan ibu pre sectio caesar. Penelitian ini sejalan dengan pendapat Ma'rifah (2016) bahwa semakin kuat kepercayaan dan keyakinan atau semakin efektif terapi benson diberikan maka cenderung tingkat kecemasan ibu pre sectio caesar akan mengalami penurunan sehingga tindakan sectio caesar dapat dilakukan tanpa ada hambatan.

Menurut asumsi peneliti berdasarkan hasil penelitian yang dilakukan bahwa terdapat perbandingan tingkat kecemasan ibu pre sectio caesar sebelum dan sesudah diberikan terapi benson sebanyak 14,3\%, sehingga dapat juga dikatakan terapi benson sangat efektif digunakan untuk menurunkan tingkat kecemasan dan juga membantu proses tindakan sectio caesarberjalan dengan baik karena kondisi fisik ibu yang baik pula.

\section{Keterbatasan Penelitian}

Keterbatasan penelitian ini, yang pertama, harus menunggu ibu yang mau presectio saecar membutuhkan waktu yang lama untuk mendapatkan sampel yang banyak karena waktu penelitian ini hanya sebulan makanya mendapatkan sampel yang tidak banyak. 
Yang kedua, peneliti laki-laki terkadang ibu tidak terlalu terbuka dengan kondisinya sehingga dibantu oleh perawat ruangan, yang ketiga, penelitian ini dilakukan sebelum operasi jadi waktu melakukan terapi terlalu sedikit dan terburu-buru, harusnya lebih baik dilakukan stelah operasi sehingga banyak waktu untuk melakukan terapi.

\section{SIMPULAN}

Berdasarkan hasil dalam penelitian dapat disimpulkan: timgkat kecemasan sebelum diberikan terapi benson pada ibu presectio caesar di RSUD Sidikalang mayoritas sedang dan tingkat kecemasan setelah diberikan terapi benson pada ibu presectio caesar di RSUD Sidikalang mayoritas ringan serta ada perbedaan sebelum dan sesudah dilakukan terapi benson terhadap tingkat kecemasan ibu pre sectio caesar di RSUD Sidikalang dengan nilai p-value $0,004(\mathrm{p}<0,05)$.

\section{REFERENSI}

Benson \& Ralph.C.(2009). Buku Saku Obstetri dan Ginekologi. Jakrta: EGC

Darmawan, I. K. E. (2015). Pengaruh Relaksasi Benson Terhadap Tekanan Darah Pada Pasien Hipertensi. Coping: Community of Publishing in Nursing, 3(1). https://ojs.unud.ac.id/index.php/coping/article/view/10824

Gorji, M. H., Davanloo, A. A., \& Heidarigorji, A. M. (2014). The efficacy of relaxation training on stress, anxiety, and pain perception in hemodialysis patients. Indian journal of nephrology, 24(6), 356. doi: 10.4103/0971-4065.132998. PMID: 25484528 .

Hastuti, D. (2015). Hubungan Pengetahuan Tentang Sectio Caesarea dengan Kecemasan Ibu Pre Operasi Di Ruang Catleya Rumah Sakit Panti Waluyo Surakarta. Skripsi S-1 keperawatan. Stikes Kusuma Husada. Surakarta. https://d1wqtxts1xzle7.cloudfront.net/53367131/01-gdl-dwihastuti-1075-11 fullt-i_1.pdf

Kiani, F., Zadeh, M. A. H., \& Shahrakipour, M. (2017). The effect of Benson's relaxation method on hemodialysis patients' anxiety. International Journal of Medical Sciences, 1(8). https://www.biomedres.info/biomedical-research/theeffect-of-bensons-relaxation-method-on-hemodialysis-patients-anxiety.html

Kurniasari, A. N., Kustanti, A., \& Harmilah, H. (2016). The Effect Benson Relaxation Technique With Anxiety In Hemod.yalisis Patients In Yogyakarta. IJNP (Indonesian Journal of Nursing Practices), 1(1), 40-47. https://journal.umy.ac.id/index.php/ijnp/article/view/2685

Marbun, A., Pardede, J. A., \& Perkasa, S. I. (2019). Efektivitas Terapi Hipnotis Lima Jari terhadap Kecemasan Ibu Pre Partum di Klinik Chelsea Husada Tanjung Beringin Kabupaten Serdang Bedagai. Jurnal Keperawatan Priority, 2(2), 9299. doi: https://doi.org/10.34012/jukep.v2i2.568

Ma'rifah, A.R (2017). Pengaruh Relaksasi Benson Terhadap Tingkat Kecemasan Pada Pasien Kanker Serviks. Universitas Harapan bangsa. http://news.uhb.ac.id/en/posts/pengaruh-relaksasi-benson-terhadap-tingkatkecemasanpada-pasien-kanker-serviks/

Pardede, Sitepu, \& Saragih. (2018). Pengaruh Teknik Relaksasi Nafas Dalam Dengan Terapi Hipnotis Lima Jari Terhadap Kecemasan Pasien Pre Operatif Di RSUD Dr. H. Kumpulan Pane Kota Tebing Tinggi. Academia. Edu. https://www.academia.edu/35996338/ 
Perdana, Y. A. (2018). Pengaruh Pemberian Teknik Relaksasi Benson Terhadap Tingkat Kecemasan Pasien Pre Operasi Katarak di RSD dr. Soebandi Jember. http://repository.unej.ac.id/handle/123456789/87497.

Otaghi, M., Borji, M., Bastami, S., \& Solymanian, L. (2016). The Effect of Benson's Relaxation on depression, anxiety and stress in patients undergoing hemodialysis. International Journal of Medical Research \& Health Sciences, $5(12)$,

76-83. http://www.indianjournals.com/ijor.aspx?target=ijor:ijmrhs\&volume=5\&issue $=12$ \&article $=014$

Rambod, M., Sharif, F., Pourali-Mohammadi, N., Pasyar, N., \& Rafii, F. (2014). Evaluation of the effect of Benson's relaxation technique on pain and quality of life of haemodialysis patients: A randomized controlled trial. International

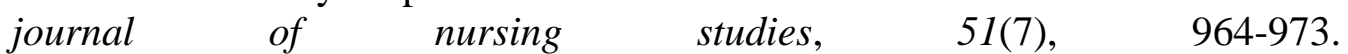
https://doi.org/10.1016/j.ijnurstu.2013.11.004

Ratnawati, D., Siregar, T., \& Wahyudi, C. T. (2018). Terapi Relaksasi Benson Termodifikasi Efektif Mengontrol Gula Darah pada Lansia dengan Diabetes Mellitus. Jurnal Kedokteran dan Kesehatan, 14(2), 83-93. doi: https://doi.org/10.24853/ikk.14.2.83-93

Riskesdas (2013). Badan Penelitian Dan Pengembangan Kesehatan Kementerian Kesehatan

RI.Jakarta.http://kesga.kemkes.go.id/images/pedoman/Data\%20Riskesdas\%20 2013.pdf

Sumelung, V., Kundre, R., \& Karundeng, M. (2014). Faktor-Faktor Yang Berperan Meningkatnya Angka Kejadian Sectio Caesarea Di Rumah Sakit Umum Daerah Liun Kendage Tahuna. Jurnal Keperawatan, 2(1). https://ejournal.unsrat.ac.id/index.php/jkp/article/view/4052

Solehati, T., \& Rustina, Y. (2015). Benson relaxation technique in reducing pain intensity in women after cesarean section. Anesthesiology and pain medicine, 5(3). doi: 10.5812/aapm.22236v2. PMID: 26161315

Wahyu, A. (2018). Efektifitas Relaksasi Benson terhadap Penurunan Nyeri Pasien Pasca Sectio Caesarea. Jurnal Keperawatan Silampari, 2(1), 236-251. doi: https://doi.org/10.31539/jks.v2i1.303

Warsono, W., Fahmi, F. Y., \& Iriantono, G. (2019). Pengaruh Pemberian Teknik Relaksasi Benson terhadap Intensitas Nyeri Pasien Post Sectio Caesarea di RS PKU Muhammadiyah Cepu. Jurnal Ilmu Keperawatan Medikal Bedah, 2(1), 44-54. doi: http://dx.doi.org/10.32584/jikmb.v2i1.244.

Yanti, Y. E. (2015). Hubungan pengetahuan ibu dan dukungan suami pada ibu hamil terhadap keteraturan kunjungan antenatal care (anc) di puskesmas wates lampung tengah tahun 2014. Jurnal Kebidanan Malahayati, 1(2). doi: https://doi.org/10.33024/jkm.v1i2.550

Yusliana, A, Misrawati, \& Safri. (2016). Efektivitas Relaksasi Benson Terhadap Penurunan Nyeri Pada Ibu Postpartumsectio Caesarea." Jurnal Online Mahasiswa Program Studi Ilmu Keperawatan Universitas Riau, vol. 2, no. 2, pp. 944-952. https://repository.unej.ac.id/handle/123456789/87497 